\title{
From Retrospective Analysis of Patients with Undifferentiated Spondyloarthritis (SpA) to Analysis of Prospective Cohorts and Detection of Axial and Peripheral SpA
}
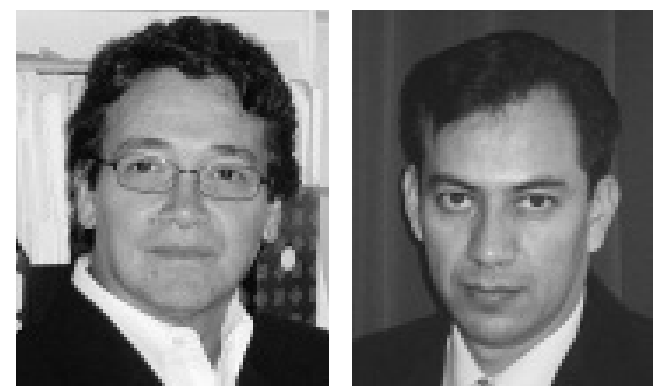

Spondyloarthritis (SpA) refers to a group of HLA-B27-positive associated rheumatic diseases that share clinical and genetic features. The diseases and conditions that constitute the SpA group are defined by signs, symptoms, and radiographic findings, and consist of ankylosing spondylitis (AS), reactive arthritis (ReA), the SpA subsets psoriatic arthritis (PsA), Crohn's disease (CD) and ulcerative colitis, and a subgroup of undifferentiated forms ${ }^{1}$.

Traditionally, patients with SpA may be classified according to Amor, et $a l^{2}$ and the European Spondylarthropathy Study Group (ESSG) ${ }^{3}$ criteria. Patients fulfilling such criteria may then be classified or diagnosed according to specific criteria, clinical picture, or diagnostic tests for AS, ReA and SpA subsets PsA, CD and ulcerative colitis, for example. In general, patients with SpA that do not fulfill such classification or diagnostic-specific criteria remain unclassified and comprise the subgroup known as undifferentiated SpA (USpA).

USpA accounts for a significant but variable proportion of patients with SpA in the open population ${ }^{4,5}$, in a group of relatives of probands with $\mathrm{AS}^{6,7}$, and in hospital-based registries of $\mathrm{SpA}^{8-10}$. As a group, USpA are mostly characterized by isolated episodes of peripheral arthritis and enthesitis, axial symptoms, and by a lower incidence of HLA-B27 versus AS.

As a group, SpA are characterized by overlapping of clinical manifestations over the disease course ${ }^{11}$. For example, patients with AS may develop psoriasis and $\mathrm{CD}$, patients with ReA may develop psoriasis, and patients with psoriasis may developed CD and AS. Similarly, patients with USpA may develop any specific clinical manifestation and fulfill specific diagnostic criteria some time later. In this context, it is clear that patients with SpA fulfilling specific criteria of more than 2 SpA constitute a "true SpA overlap," while patients presenting with nonspecific or isolated manifestations of SpA without fulfilling specific SpA diagnostic or classification criteria constitute the group of USpA.
The series of events over the course of SpA, from undifferentiated to definite to overlapping, can take a variable amount of time and, as expected, no definition of this variable can be considered as a parameter to be fulfilled in classification or diagnostic criteria. Time definition may be of relevance in diagnosing or classifying patients with USpA and patients classified as axial and peripheral SpA according to the Assessment in Spondyloarthritis International Society (ASAS) new criteria ${ }^{12,13}$. Two related questions in this regard are simple but difficult to answer: How long should USpA be considered the earliest form of definite $\mathrm{SpA}$ (e.g., AS), or be considered a particular form of SpA that never evolves into definite SpA? Although we don't know the answer, there is information from studies assessing longterm outcome in USpA and looking for prognostic factors.

In this issue of The Journal, Sampaio-Barros, et $a l^{14}$ present data on 5 to 10-year followup in patients with USpA fulfilling ESSG criteria ${ }^{3}$ who have no radiographic sacroiliitis, psoriasis, $\mathrm{CD}$, ulcerative colitis, or triggering infection. By 10-year followup, a relatively low $35 \%$ of 42 patients with USpA had progressed to AS. In their article ${ }^{14}$ and in most longterm studies of USpA, we may recognize 2 of the 4 types of USpA proposed by Zeidler, et al ${ }^{15}$ : (1) a subgroup of patients representing the early stage of a definite, well categorized SpA (e.g., AS); and (2) a second subgroup consisting of patients with definite USpA. According to Sampaio-Barros, et $a l^{14}$ and other findings ${ }^{16,17}$, an additional subcategory of patients in the latter subgroup would include those going into remission.

Origin of USpA. The recognition of clinical forms that later became USpA dates back to Khan, et al ${ }^{18}$ and Prakash, et al ${ }^{19}$ in 1983, and Burns and Calin ${ }^{20}$ in 1984, in which they described this subgroup of patients. This type of patient has since been recognized, classified, and diagnosed according to the most common features, particularly peripheral arthritis, enthesitis, and extraarticular symptoms. Patients were also

See Undifferentiated SpA: Longterm followup, page 1195

Personal non-commercial use only. The Journal of Rheumatology Copyright @ 2010 . All rights reserved. 
followed up over years to determine the proportion fulfilling AS criteria ${ }^{21}$ and to identify factors involved in the process.

Retrospective studies on outcome in USpA. Short and longterm followup studies referred to AS as the most important outcome in USpA. In 2 shorter followup studies, the proportion of patients fulfilling AS criteria 24 and 28 months after onset were $10 \%^{22}$ and $36 \%^{23}$, respectively. In the Schattenkirchner and Krüger study ${ }^{24}$, the percentage reached $25 \%$ within 2 to 6 years, versus Huerta-Sil's finding of $42 \%$ by 3 years after symptom onset ${ }^{25}$. Two further studies ${ }^{16,26}$ found AS in $25 \%$ and $36 \%$ by 5 years after onset. Few followup studies reached 10 years or more. Interestingly, however, the proportion of patients with AS as reported by Mau, et $a l^{16}$ and Kumar, et $a l^{17}$ was $66 \%$ and $68 \%$ at 10 - and 11-year followup; this is in contrast with Sampaio-Barros's ${ }^{14}$ present report, in which only $35.7 \%$ of the patients were diagnosed as having AS 10 years after onset.

The outcome of patients not fulfilling AS criteria has been scarcely reported. In Kumar's study ${ }^{17} 2$ (9\%) patients entered into remission and one (4.5\%) developed PsA. In Mau's longterm followup ${ }^{16}$ one $(1.1 \%)$ patient had self-limited disease and $2(2.2 \%)$ PsA. Sampaio-Barros, et al ${ }^{14}$ report that $40.5 \%$ entered into remission, $16.7 \%$ remained undifferentiated, and $7.1 \%$ developed PsA.

In children, the proportion of patients with USpA and USpA-like clinical forms fulfilling AS criteria throughout the followup period ranges from $66 \%$ to $90 \%$ within 10 years of disease $\mathrm{e}^{27-30}$.

Some descriptions do not refer to AS as an outcome measure. In Sambrook's followup ${ }^{31}$ of patients with HLA-B27 associated peripheral arthritis, $10 \%$ of patients fulfilled ReA triad criteria and $55 \%$ entered into remission. However, there was only one case with $\mathrm{SpA}$ and no case with AS diagnosed during followup. On the other hand, a number of papers have referred to "late-onset $\mathrm{SpA}$ " as $\mathrm{SpA}$ starting after age 50 years $^{32-35}$. Clinical manifestations in this group are also diverse, but mainly consist of peripheral joint involvement. Remarkably, presence of systemic and extrarticular manifestations indicates the need for careful assessment to rule out a number of diverse conditions. To date, there is still no information on the percentage of patients with late-onset SpA evolving into AS or definite SpA.

Differences across studies mentioned above seem to be related to disease definition at the time of inclusion. Diagnosis varied from "HLA-B27-negative associated oligoarthritis"24 to "possible ankylosing spondylitis"16, "possible SpA"26, and "undifferentiated SpA"17,22,25. Disease duration in various studies extended more than 10 years (i.e., the sum of the duration of the disease at baseline and the duration of followup); therefore, diagnosis of USpA does not necessarily mean early or recent SpA. Further explanations of differences between studies include the assessment and outcome measures and ethnicity.

Most patients with USpA present with any of 3 types of symptoms: peripheral arthritis, inflammatory back pain (IBP), and a combination of peripheral arthritis and IBP. Definitely, the type of $\mathrm{SpA}$ symptoms at presentation depends on the definition of disease at time of study inclusion.

Manifestations at onset. The presentation of SpA in Mau, et $a l^{16}$ was mostly axial, whereas in Kumar, et $a l^{30}$, disease most frequently affected peripheral sites. Although inclusion criteria for most studies were mainly oriented to peripheral arthritis, Mau, et $a l^{16}$ included patients with possible AS. In contrast, studies from Sampaio-Barros, et $a l^{22}$, Huerta-Sil, et $a l^{25}$, and Kumar, et $a l^{17}$ relied on ESSG criteria ${ }^{3}$. Enthesitis, dactylitis, anterior uveitis, inflammatory bowel disease, cardiac rhythm disturbances, or other symptoms may occur as the earliest manifestation of USpA.

Some studies have been performed in Europe $16,23,24,26$, and some in Latin America ${ }^{14,22,25}$ and Asia ${ }^{17}$. Although no formal comparisons between ethnic groups have been made, retrospective reviews of patients with AS have shown that Caucasians from Europe and North America present with IBP more often than patients from Latin America, Asia, the Middle East, and Africa, where peripheral symptoms are much more common ${ }^{36,37}$. Differences between ethnic groups might reflect not only the influence of genetic factors, but also a role for geographical or environmental factors.

USpA as an early form of AS. The identification of patients with USpA could enable physicians to recognize patients with AS at an earlier stage and treat them accordingly. Overall, diagnosis of $\mathrm{AS}^{21}$, which requires a certain level of sacroiliac joint damage to be visible on radiographs, is usually, but not always, made around 8 years after onset ${ }^{38}$. Response to tumor necrosis factor- $\alpha$ (TNF- $\alpha$ ) blockers, as measured by the proportion of patients reaching $50 \%$ or greater reduction in the Bath Ankylosing Spondylitis Disease Activity Index (BASDAI), surpasses $70 \%$ in patients with disease duration $<10$ years, but is scarcely $30 \%$ in patients with duration $>20$ years ${ }^{39,40}$.

Fulfillment of AS criteria ${ }^{21}$ by patients with USpA in the course of disease has been inconsistently associated with baseline characteristics, specifically uveitis ${ }^{16,25,26}$, HLA-B2 $7^{16,22}$, alternate gluteal pain ${ }^{22}$, peripheral arthritis ${ }^{23}$, high erythrocyte sedimentation rate ${ }^{16}$, or C-reactive protein $(\mathrm{CRP})^{25}$, recurrent oligoarthritis ${ }^{24}$, and low-grade radiographic sacroiliitis ${ }^{25}$. However, only the reports by Huerta-Sil, et $a l^{25}$ and Sampaio-Barros, et $a l^{14}$ have identified risk factors for AS in patients with USpA. Huerta-Sil, et $a l^{25}$ found radiographic sacroiliitis grade $<2$ bilateral, or grade < 3 unilateral (OR 11.18, 95\% CI 2.59, 48.16; p = 0.001 ), particularly grade 1 bilateral (OR 12.58, 95\% CI $1.33,119.09 ; \mathrm{p}=0.027$ ), and previous uveitis (OR 19.25, $95 \%$ CI 1.72, 214.39; $\mathrm{p}=0.001)$ to be prognostic of AS; and Sampaio-Barros, et $a l^{14}$ found risk factors HLA-B27 (OR $6.720,95 \%$ CI $11.45,39.43 ; \mathrm{p}=0.035)$ and buttock pain (OR

Personal non-commercial use only. The Journal of Rheumatology Copyright @ 2010. All rights reserved. 
$6.211,95 \%$ CI 1.591, 24.25; $\mathrm{p}=0.009)$. Additional risk has been identified in prospective cohort analysis (see below).

Relationship between USpA and axial and peripheral SpA. With the rationale that the earlier the diagnosis of AS, the better the effect of treatment on disease activity, Rudwaleit, et $a l^{41}$ developed the concept of axial SpA for the classification of patients with IBP, sacroiliitis on magnetic resonance imaging (MRI), HLA-B27, and one or more SpA clinical features. Rudwaleit, et $a l^{41}$ calculated risk of AS in patients with $\mathrm{SpA}$ with information from published articles and proposed an algorithm for recognition of axial SpA and risk factors for AS. In summary, the risk of AS in patients with axial SpA increased significantly with the positivity of either MRI or HLA-B27.

The Rudwaleit study ${ }^{41}$ proposal derived into the ASAS classification criteria for axial and peripheral $\mathrm{SpA}^{12,13}$. Today, the concept behind axial SpA refers not only to the nonradiographic sacroiliitis stage of AS, but also to a wider spectrum embracing all types of SpA that includes peripheral SpA. Regarding ASAS criteria for axial SpA - with inclusion of MRI and HLA-B27 - their performance is better than $\mathrm{ESSG}^{3}$ and $\mathrm{Amor}^{2}$ criteria for $\mathrm{SpA}^{12}$.

Development of such criteria and algorithms provides the clinician, particularly the orthopedic surgeon and general practitioner, with diagnostic strategies to differentiate IBP from mechanical back pain and peripheral arthritis related to SpA from other forms of arthritis. A redefinition of IBP, HLA-B27 testing, and use of MRI for identification of sacroiliac joint inflammation are strategies for better recognition of patients with axial USpA and referral to the rheumatologist to diagnose the inflammatory stage of axial or peripheral SpA and determine risk of structural damage.

The role of axial SpA as a predictor of AS is still unknown. Heuft-Dorenbosch, et $a l^{42}$ found that in patients with IBP for less than 2 years, $\mathrm{ESSG}^{3}$ was the best instrument for classification of $\mathrm{SpA}$, followed by criteria of $\mathrm{Amor}^{2}$, and lastly Rudwaleit, et $a l^{41}$. Of note, Heuft-Dorenbosch, et a ${ }^{42}$ concluded that the contribution of HLA-B27 and MRI to the criteria by $\mathrm{Amor}^{2}$ and $\mathrm{ESSG}^{3}$ in diagnosing axial SpA was limited. More recently, in patients referred by orthopedists and primary care physicians because of back pain longer than 3 months and age at onset younger than 45 years, Brandt, et $a l^{43}$ showed that IBP, HLA-B27, and MRI-observed sacroiliitis performed well in detecting axial $\mathrm{SpA}(\mathrm{SpA}$ in that study included AS and axial USpA). The diagnosis of axial SpA was made in $34.2 \%$ of cases if one parameter was present and in $62.6 \%$ of cases if more than one parameter was positive.

HLA-B27 testing and MRI studies of the sacroiliac joints have become more accessible in recent years, but even in certain developed nations and certainly in developing countries, their use as diagnostic tools is still restricted for economic reasons.

Early SpA: Data from early SpA clinics and cohorts. There is important information derived from the study of patients with SpA and particularly USpA with short disease duration. Although the purpose, inclusion criteria, and variables analyzed differ across different studies, each provides data on percentages of patients fulfilling AS and other definite SpA criteria shortly after onset, and the characteristics of early disease.

The Maastricht early SpA clinic (ESPAC) study of 68 patients with IBP with $<2$ years of symptoms referred from various clinical departments ${ }^{42}$ showed that 14 patients developed AS within 2 years of symptoms and 36 developed $\mathrm{SpA}$ according to $\mathrm{Amor}^{2}, \mathrm{ESSG}^{3}$, and Berlin ${ }^{41}$ criteria. PsA accounted for $24 \%$ and IBD and uveitis for $15 \%$ each. Based on real-world findings, that report proposes modifications to improve the diagnostic properties of the Berlin algorithm ${ }^{41}$, specifically the step in which MRI and HLA-B27 investigations should be ordered in patients with IBP.

In the Leeds IBP clinic ${ }^{44}, 13$ (33.3\%) of 40 patients with IBP with $<2$ years of symptoms had AS (HLA-B27 in 85\%) after around 8 years of followup; 2 cases each were associated with IBD or reactive arthritis, and one with psoriasis. Of the 27 patients without AS, 3 had psoriatic SpA, 6 had reactive $\mathrm{SpA}, 1$ had IBD SpA, and 17 had undifferentiated SpA. MR sacroiliitis ( $\mathrm{n}=10$ at baseline, all HLA-B27-positive) had $92 \%$ specificity for AS. Combined moderate and severe MR sacroiliitis, regardless of HLA-B27 status, yielded $62 \%$ specificity and $77 \%$ sensitivity for AS. The likelihood ratio of combined severe MR sacroiliitis and HLA-B27 was 8.0 for AS.

The German Spondyloarthritis Inception Cohort (GESPIC) $^{45}$ included 226 patients (mean age $36.1 \pm 10.6$ yrs; $42.9 \%$ male) with axial SpA (nonradiographic SpA or radiographic sacroiliitis grades 0 or 1) whose disease duration was $2.6 \pm 1.7$ years. The manifestations that most frequently occurred in this group were IBP $(100 \%)$, peripheral arthritis (40.9\%), peripheral enthesitis (43.6\%), uveitis (12.4\%), psoriasis (9.8\%), dactylitis (4.0\%), and IBD (1.8\%). Male sex was a risk factor for developing radio-graphic sacroiliitis (OR 2.38, 95\% CI 1.9, 4.7; p = 0.014 ) and $>1$ syndesmophyte (OR 2.40, 95\% CI 1.05, 5.5; $\mathrm{p}=0.039) ; \mathrm{CRP} \leq 6 \mathrm{mg} / \mathrm{l}$ was a risk factor for developing the latter (OR 2.59, 95\% CI 1.23, 5.45; $\mathrm{p}=0.012)$ and for > 1 bridging syndesmophyte (OR 2.89, 95\% CI 1.07, 7.79; $\mathrm{p}=0.036$ ).

The Spanish Registry of SpA (Registro Español de Espondiloartritis de la Sociedad Española de Reumatología or REGISPONSER) $)^{46}$ includes data of 150 patients with SpA with $\leq 2$ years of disease, whose diagnoses were PsA-SpA in 51, AS in 46, USpA in 41 , ReA in 5, IBD arthropathy in 4, and juvenile arthritis in 1 . Mean age in USpA was $36.3 \pm 11.5$ years at onset and disease duration $1.5 \pm 0.7$ years; $58 \%$ were men and prevalence of HLA-B27 was $66 \%$. Within 2 years of disease, most patients with USpA had axial symptoms [ $\mathrm{n}=41(96 \%)]$, which consist-

Personal non-commercial use only. The Journal of Rheumatology Copyright @ 2010 . All rights reserved. 
ed of low back pain $[\mathrm{n}=24(56 \%)]$, sacroiliac syndrome [n $=15(35 \%)]$, or neck pain $[\mathrm{n}=2(5 \%)]$. Peripheral arthritis affecting the upper limbs or lower limbs occurred in 7 $(16 \%)$ and $15(35 \%)$ patients, and dactylitis in $3(7 \%)$ or enthesitis in $12(28 \%)$. A comparison between that group and patients with $>10$ years of disease $(n=122)$ revealed a nonsignificant decrease of the prevalence of each variable, excepting enthesitis, which changed from $28 \%$ to $15 \%$ ( $\mathrm{p}=$ $0.05)$.

The Iberoamerican Registry of Spondyloarthritis (Registro de Espondiloartritis de Iberoamérica or RESPONDIA $)^{47}$ has gathered information from 10 countries. RESPONDIA includes 180 patients with USpA whose mean age and duration of disease were $38.1 \pm 12.9$ years and 11.9 \pm 15.4 years, respectively. Yet around $25 \%$ of these patients had disease duration $<2$ years. Preliminary data suggest that most patients with USpA present to clinic with peripheral rather than axial symptoms and that a significant percentage of them have axial and peripheral involvement throughout the disease course.

It is noteworthy that a significant proportion of patients in the above studies were diagnosed with AS in less than $2^{42,45}$ or $5^{44}$ years of disease. These findings suggest that diagnosis of AS in some patients made early in the disease course is at a time when the effect of TNF- $\alpha$ blockers may be significant.

GESPIC $^{44}$, REGISPONSER ${ }^{45}$, and RESPONDIA ${ }^{46}$ compared clinical features of USpA with those found in patients with AS. While disease duration of AS and USpA in the GESPIC group was significantly different, the REGISPONSER comparison included patients with AS and USpA with $<2$ years of symptoms. Overall, the comparison between USpA and AS in the 3 studies $^{44-46}$ showed a lower prevalence of women and HLA-B27-positive patients in the group of USpA, and more severe disease in patients with AS in regard to radiographic findings and patient self-reported outcome measures. There were differences between groups regarding the prevalence of some clinical symptoms, but the disease pattern was rather similar. At first glance, short-term USpA resembles early stage AS.

Adapting to new names and classification criteria. We are going through a transition: from SpA to axial and peripheral SpA, from ESSG and Amor criteria to ASAS axial and peripheral criteria, and from retrospective studies to prospective cohorts and early SpA or IBP clinics. A series of strategies is leading to a common end: to identify patients with SpA in the early inflammatory stage and those at risk of developing structural change or damage, in order to provide them with effective therapy as early as possible. While the longterm efficacy of new therapies, specifically disease-modifying TNF blockers, is still to be determined, their role in disease remission warrants their use for symptom control and improvement of health related quality of life.

\section{RUBEN BURGOS-VARGAS, $\mathrm{MD}$,}

Senior Investigator and Professor of Medicine,

Department of Rheumatology, Hospital General de México,

Faculty of Medicine, Universidad Nacional Autónoma de México;

JULIO C. CASASOLA-VARGAS, MD,

Staff Rheumatologist,

Department of Rheumatology,

Hospital General de México,

Dr. Balmis 148, colonia Doctores,

México DF 06720

Address correspondence to Prof. Burgos-Vargas;

E-mail:burgosv@prodigy.net.mx

\section{REFERENCES}

1. Khan MA. Update on spondyloarthropathies. Ann Intern Med 2002;136:896-907.

2. Amor B, Dougados M, Mijiyawa M. Criteria of the classification of spondylarthropathies [French]. Rev Rhum Mal Osteoartic 1990;57:85-9.

3. Dougados M, van der Linden S, Juhlin R, Huitfeldt B, Amor B, Calin A, et al. The European Spondylarthropathy Study Group preliminary criteria for the classification of spondylarthropathy. Arthritis Rheum 1991;34:1218-27.

4. Boyer GS, Templin DW, Bowler A, Lawrence RC, Heyse SP, Everett DF, et al. Spondyloarthropathy in the community: clinical syndromes and disease manifestations in Alaskan Eskimo populations. J Rheumatol 1999;26:1537-44.

5. Roux CH, Saraux A, Le Bihan E, Fardellone P, Guggenbuhl P, Fautrel B, et al. Rheumatoid arthritis and spondyloarthropathies: geographical variations in prevalence in France. J Rheumatol 2007;34:117-22.

6. Chou CT, Lin KC, Wei JC, Tsai WC, Ho HH, Hwang CM, et al. Study of undifferentiated spondyloarthropathy among first-degree relatives of ankylosing spondylitis probands. Rheumatology 2005;44:662-5.

7. Porcher R, Said-Nahal R, D’Agostino MA, Miceli-Richard C, Dougados M, Breban M. Two major spondylarthropathy phenotypes are distinguished by pattern analysis in multiplex families. Arthritis Rheum 2005;53:263-71.

8. Baddoura R, Awada H, Okais J, Habis T, Attoui S, Abi Saab M. Validation of the European Spondylarthropathy Study Group and B. Amor criteria for spondylarthropathies in Lebanon. Rev Rhum Engl Ed 1997;64:459-64.

9. Howe HS, Zhao L, Song YW, Springer L, Edmonds J, Gu J, et al. Seronegative spondyloarthropathy - studies from the Asia Pacific region. Ann Acad Med Singapore 2007;36:135-41.

10. Collantes E, Zarco P, Muñoz E, Juanola X, Mulero J, Fernández-Sueiro JL, et al. Disease pattern of spondyloarthropathies in Spain: description of the first national registry (REGISPONSER) - extended report. Rheumatology 2008;67:782-8.

11. Burgos-Vargas R. Undifferentiated spondyloarthritis: A global perspective. Curr Rheumatol Rep 2007;9:361-366

12. Rudwaleit M, van der Heijde D, Landewé R, Listing J, Akkoc N, Brandt J, et al. The development of Assessment of SpondyloArthritis international Society classification criteria for axial spondyloarthritis (part II): validation and final selection. Ann Rheum Dis 2009;68:777-83

13. Rudwaleit M, van der Heijde D, Landewé R, et al. New ASAS classification criteria for peripheral spondyloarthritis [abstract]. Ann Rheum Dis 2009;68 Suppl3:127.

14. Sampaio-Barros P, Bortoluzzo AB, Conde RA, Costallat LTL, Samara AM, Bértolo MB. Undifferentiated spondyloarthritis: A long-term follow-up. J Rheumatol 2010;37:1195-9.

Personal non-commercial use only. The Journal of Rheumatology Copyright $\subset$ 2010. All rights reserved. 
15. Zeidler H, Mau W, Khan MA. Undifferentiated spondyloarthropathies. Rheum Dis Clin North Am 1992;18:187-202.

16. Mau W, Zeidler H, Mau R, Majewski A, Freyschmidt J, Stangel W, et al. Clinical features and prognosis of patients with possible ankylosing spondylitis. Results of a 10-year followup. J Rheumatol 1988;15:1109-14.

17. Kumar A, Bansal M, Srivastava DN, Pandhi A, Menon A, Mehra $\mathrm{NK}$, et al. Long-term outcome of undifferentiated spondylarthropathy. Rheumatol Int 2001;20:221-4.

18. Khan MA, van der Linden S, Kushner I. Symptomatic ankylosing spondylitis without radiographic sacroiliitis in B27 positive relatives. Clin Res 1983;31:804A.

19. Prakash S, Bansal R, Rajgopalan P, Malaviya AN. Immunological studies in seronegative spondyloarthropathies. Br J Rheumatol 1983;22:146-50.

20. Burns TM, Calin A. Undifferentiated spondyloarthropathy. In: Calin A, editor. Spondyloarthropathies. Orlando, FL: Grune \& Stratton; 1984:253-64.

21. van der Linden S, Valkenburg HA, Cats A. Evaluation of diagnostic criteria for ankylosing spondylitis. A proposal for modification of the New York criteria. Arthritis Rheum 1984;27:361-8.

22. Sampaio-Barros PD, Bertolo MB, Kraemer MH, Marques-Neto JF, Samara AM. Undifferentiated spondyloarthropathies: a 2-year follow-up study. Clin Rheumatol 2001;20:201-6.

23. Sany J, Rosenberg F, Panis G, Serre H. Unclassified HLA-B27 inflammatory rheumatic diseases: followup of 23 patients. Arthritis Rheum 1980;23:258-9.

24. Schattenkirchner M, Krüger K. Natural course and prognosis of HLA-B27-positive oligoarthritis. Clin Rheumatol 1987;6 Suppl 2:83-6.

25. Huerta-Sil G, Casasola-Vargas JC, Londoño JD, Rivas-Ruíz R, Chávez J, Pacheco-Tena C, et al. Low grade radiographic sacroiliitis as prognostic factor in patients with undifferentiated spondyloarthritis fulfilling diagnostic criteria for ankylosing spondylitis throughout follow up. Ann Rheum Dis 2006;65:642-6.

26. Collantes E, Veroz R, Escudero A, Muñoz E, Muñoz MC, Cisnal A, et al. Can some cases of 'possible' spondyloarthropathy be classified as 'definite' or 'undifferentiated' spondyloarthropathy? Value of criteria for spondyloarthropathies. Spanish Spondyloarthropathy Study Group. Joint Bone Spine 2000;67:516-20.

27. Hall MA, Burgos-Vargas R, Ansell BM. Sacroiliitis in juvenile chronic arthritis: a 10-year follow-up. Clin Exp Rheumatol 1987;5 Suppl:65-7.

28. Burgos-Vargas R, Clark P. Axial involvement in the seronegative enthesopathy and arthropathy syndrome and its progression to ankylosing spondylitis. J Rheumatol 1989;16:192-7.

29. Cabral DA, Oen KG, Petty RE. SEA syndrome revisited: a longterm followup of children with a syndrome of seronegative enthesopathy and arthropathy. J Rheumatol 1992;19:1282-5.

30. Burgos-Vargas R, Vázquez-Mellado J. The early clinical recognition of juvenile-onset ankylosing spondylitis and its differentiation from juvenile rheumatoid arthritis. Arthritis Rheum 1995;38:835-44.

31. Sambrook P, McGuigan L, Champion D, Edmonds J, Fleming A, Portek I. Clinical features and followup study of HLA-B27 positive patients presenting with peripheral arthritis. J Rheumatol 1985;12:526-8.

32. Dubost JJ, Sauvezie B. Late onset peripheral spondyloarthropathy. J Rheumatol 1989;16:1214-7.

33. Olivieri I, Padula A, Pierro A, Favaro L, Oranges GS, Ferri S. Late onset undifferentiated seronegative spondyloarthropathy. J Rheumatol 1995;22:899-903.
34. Caplanne D, Tubach F, Le Parc JM. Late onset spondylarthropathy: clinical and biological comparison with early onset patients. Ann Rheum Dis 1997;56:176-9.

35. Olivieri I, Salvarani C, Cantini F, Ciancio G, Padula A. Ankylosing spondylitis and undifferentiated spondyloarthropathies: a clinical review and description of a disease subset with older age at onset. Curr Opin Rheumatol 2001;13:280-4.

36. Lau CS, Burgos-Vargas R, Louthrenoo W, Mok MY, Wordsworth P, Zeng QY. Features of spondyloarthritis around the world [review]. Rheum Dis Clin North Am 1998;24:753-70.

37. Hajjaj-Hassouni N, Burgos-Vargas R. Ankylosing spondylitis and reactive arthritis in the developing world. Best Pract Res Clin Rheumatol 2008;22:709-2.

38. Feldtkeller E, Khan MA, van der Heijde D, van der Linden S, Braun J. Age at disease onset and diagnosis delay in HLA-B27 negative vs. positive patients with ankylosing spondylitis. Rheumatol Int 2003;23:61-6

39. Rudwaleit M, Listing J, Brandt J, Braun J, Sieper. Prediction of a major clinical response (BASDAI 50) to tumour necrosismajor clinical response (BASDAI 50) to tumour necrosis factor alpha blockers in ankylosing spondylitis. Ann Rheum Dis 2004;63:665-70.

40. Sieper J, Rudwaleit M. How early should ankylosing spondylitis be treated with tumour necrosis factor blockers? Ann Rheum Dis 2005;64 Suppl 4:iv61-4.

41. Rudwaleit M, van der Heijde D, Khan MA, Braun J, Sieper J. How to diagnose axial spondyloarthritis early. Ann Rheum Dis 2004;63:535-43

42. Heuft-Dorenbosch L, Landewé R, Weijers R, Houben H, van der Linden $\mathrm{S}$, Jacobs $\mathrm{P}$, et al. Performance of various criteria sets in patients with inflammatory back pain of short duration; the Maastricht early spondyloarthritis clinic. Ann Rheum Dis 2007;66:92-8.

43. Brandt HC, Spiller I, Song IH, Vahldiek JL, Rudwaleit M, Sieper J Performance of referral recommendations in patients with chronic back pain and suspected axial spondyloarthritis. Ann Rheum Dis 2007;66:1479-84.

44. Bennett AN, McGonagle D, O'Connor P, Hensor EM, Sivera F, Coates LC, et al. Severity of baseline magnetic resonance imaging-evident sacroiliitis and HLA-B27 status in early inflammatory back pain predict radiographically evident ankylosing spondylitis at eight years. Arthritis Rheum 2008;58:3413-8.

45. Rudwaleit M, Haibel H, Baraliakos X, Listing J, Märker-Hermann $\mathrm{E}$, Zeidler $\mathrm{H}$, et al. The early disease stage in axial spondylarthritis: results from the German Spondyloarthritis Inception Cohort. Arthritis Rheum 2009;60:717-27.

46. Rojas-Vargas M, Muñoz-Gomariz E, Escudero A, Font P, Zarco P, Almodovar R, et al, and Registro Español de Espondiloartritis de la Sociedad Española de Reumatología Working Group. First signs and symptoms of spondyloarthritis - data from an inception cohort with a disease course of two years or less (REGISPONSER-Early). Rheumatology 2009;48:404-9.

47. Vazquez-Mellado J, Font P, Azevedo V, et al. Disease patterns in patients with spondyloarthropathies (SpA) from Iberoamérica (IBA): The Respondia group report [abstract]. Ann Rheum Dis 2008;67 Suppl II:627.

J Rheumatol 2010;37:1091-5; doi:10.3899/jrheum.100413 